\title{
Present and future directions for a Vi polysaccharide vaccine in preventing Typhoid fever
}

\author{
R. Dumas ${ }^{1}$, D. Chassard ${ }^{2}$, F. Tron ${ }^{3}$, H. Salomon ${ }^{4}$, C. Blondeau ${ }^{5}$, M. Moreau ${ }^{1}$, N. Bouveret-Le Cam ${ }^{4}$
}

\begin{abstract}
Abstrak
Dua pendekatan yang saling melengkapi pada saat ini dikembangkan untuk memperbaiki dan meningkatkan penggunakan vaksin Vi polisakarida kapsul (CPS). Dilakukan studi vaksin konjugat yang terdiri dari Vi digabung dengan toxoid tetanus murni (Vi-TT) pada percobaan fase I pada 52 orang dewasa, umur 19-33 tahun. Dua injeksi (i.m) vaksin diberikan berjarak waktu 1 bulan, dan dibandingkan dengan satu injeksi Typhim Viß $(0,025 \mu \mathrm{g}$ Pasteur Mérieux Connaught, Lyon, France), diikuti dengan satu injeksi plasebo. Tidak terdapat reaksi yang tidak diinginkan setelah setiap suntikan. Kadar anti-Vi yang diukur dengan RIA sebelum dan 4 minggu setelah suntikan pertama memberikan indikasi bahwa semua subyek penelitian di dalam grup Vi-TT adalah seroprotected ( $\geq 1 \mu \mathrm{g} / \mathrm{ml})$ setelah vaksinasi, dibandingkan dengan 88,5\% orang yang hanya diberi Vi saja. Serokonversi, (kenaikan 4 kali di atas baseline), diperoleh dari 80,7\% dari orang yang mendapat Vi-TT setelah suntikan pertama, dan meningkat menjadi $84,6 \%$ setelah injeksi kedua, dibandingkan dengan 73,0\% dan 69,2\% pada vaksinasi Vi saja. Dosis kedua vaksin Vi-TT tidak meningkatkan respon, tetapi secara bermakna ditemukan titer antibodi yang lebih tinggi pada grup Vi-TT (GMT 6,8 $\mu \mathrm{g} / \mathrm{ml})$ dibandingkan dengan kelompok Typhim Vi® $(G M T 3,0 \mu \mathrm{g} / \mathrm{ml})$. Dilakukan studi vaksin kombinasi yang mengandung antigen hepatitis A (Avaxim ${ }^{\mathrm{TM}}$, Pasteur Mérieux Connaught, Lyon, France; 160 unit antigen) dan vaksin Typhim $V i \circledast$ pada percobaan fase 1, terdiri dari 45 orang dewasa berumur 18-38 tahun, yang diberikan vaksin dosis tunggal (i.m). Tidak ditemukan reaksi yang tidak diinginkan. Empat minggu kemudian, $90,9 \%$ orang mengalami serokonversi antibodi anti-Vi, dan $86,4 \%$ adalah seroprotected. Anti-Vi GMT (RIA) meningkat dari $0,15 \mu \mathrm{g} / \mathrm{ml}$ sebelum vaksinasi menjadi $2,04 \mu \mathrm{g} / \mathrm{ml}$. Hasil serologi untuk individu yang pada awalnya HAV-negatif m̈emuaskan dengan anti-HAV GMT (modified RIA) adalah 176,9 $\mu \mathrm{g} / \mathrm{ml}$ dalam 4 minggu setelah injeksi dan semua subyek menjadi seroprotected $(20 \mu \mathrm{g} / \mathrm{ml})$.
\end{abstract}

\begin{abstract}
Two complementary approaches are curently under development to improve and extend the use of the Vicapsular polysaccharide vaccine. One approach is to conjugate the polysaccharide antigen to a protein carrier. The other is to combine the vaccine with the hepatitis $A$ antigen. The tolerance and immunogenicity of a conjugate vaccine consisting of $V i$ coupled to a purified, detoxified tetanus toxoid (Vi-TT) were studied in a phase I trial in 52 adults, aged 19 to 33 years. Two intramuscular injections of the vaccine were given injection of Typhim $V i \circledast(0.025 \mu \mathrm{g}$, Pasteur Mérieux Connaught, Lyon, France) followed one month later by a similar injection of placebo. There was no serious adverse event after any of the injections. Anti-Vi antibody levels, measured by radio-immunoassay (RIA) before and 1 weeks after first injection, indicated that all subjects in the Vi-TT group were seroprotected $(\geq 1 \mu \mathrm{g} / \mathrm{ml})$ after vaccination, compared to $88.5 \%$ of those who received Vi alone. Seroconversion, defined by 4 -fold increase over baseline of total serum anti-Vi, was achieved by $80.7 \%$ of $V i-T T$ vaccinees after the first injection, increasing to $84.6 \%$ after the second injection, compared to $73.0 \%$ and $69.2 \%$ with $V i$ alone. As anticipated, the second dose of Vi-TT did not elicit a booster response. After the second dose of vaccine, significantly higher antibody titres were found in the Vi-TT group (GMT $6.8 \mu \mathrm{g} / \mathrm{ml}$ ) compared with the Typhim Vi® group (GMT 3.0 $\mu \mathrm{g} / \mathrm{ml}$ ). Typhoid fever and hepatitis $A$ are two contagious diseases transmitted via the faecal-oral route, A combined vaccine containing a hepatitis $A$ vaccine (Avaxim $^{\mathrm{TM}}$, Pasteur Mérieux Connaught, Lyon, France; 160 antigen units) and the Typhim Vi® was studied in a phase I trial, in 45 adults aged 18 to 38 years, receiving a single dose of the combined vaccine by intramuscular route. No significant adverse event was observed. Four weeks after injection, $90.9 \%$ of enrolled subject seroconverted for anti-Vi antibody (4-fold increase), and $86.4 \%$ were considered seroprotected $(\geq I \mu \mathrm{g} / \mathrm{ml})$. The anti-Vi antibody $G M T$ value $(R I A)$ increased from $0.15 \mu \mathrm{g} / \mathrm{ml}$ before vaccination to $2.04 \mu \mathrm{g} / \mathrm{ml}$. Serological result of initially HAV-negative subjects were satisfactory, with a anti-HAV antibody GMT (modified RIA) of $176.9 \mu \mathrm{g} / \mathrm{ml}$ four weeks after injection, and all subjects being seroprotected $(\geq 20 \mu \mathrm{g} / \mathrm{ml})$. In the coming years, we can look forward to important advances in the development of these new vaccines that will be of benefit to both children and adults living in countries endemic for these infectious diseases.
\end{abstract}

\footnotetext{
${ }^{1}$ Pasteur Mérieux Connaught,

58 avenue Leclerc, B.P. 7046, 69348 Lyon Cedex 07, France;

${ }^{2}$ Hospital Charles Nicolle, Rouen, France;

${ }^{3}$ Institut Aster, Paris, France;

${ }_{5}^{4}$ Pasteur Mérieux Connaught, 3 ave Pasteur, Marnes-la Coquette, France;

${ }^{5}$ Pasteur Mérieux Connaught Sero-Immunologie Clinique,

Parc Industrial d'Incarville, Val de Reuil, France.
} 
Typhoid fever (TF) continues to be a global health problem in many developing countries despite antibiotic treatment and vaccination programs. As the vaccination is the simplest means to achieve prophylaxis, various improvements of typhoid vaccines are under investigation. Two complementary approaches are currently being developed to extend the use of Vi polysaccharide vaccine: conjugation to a protein carrier that confers T-cell dependent immunity; and combination with hepatitis A vaccine, which could be useful in simultaneously controlling both faecal-oral diseases.

Various authors have shown that virulence of the causative agent of TF, Salmonella typhi, is correlated with the presence of the capsular polysaccharide (CPS) antigen, $\mathrm{Vi}$, which is regularly present in strains isolated from blood cultures of patients with TF. In view of the similarities between TF and invasive diseases caused by other encapsulated bacteria for which purified CPS vaccines exist, a vaccine composed of the $\mathrm{Vi}$ antigen extracted from the the capsule of S. typhi TY2 has been developed (Typhim Vi®, Pasteur Mérieux Connaught, Lyon, France; $0.025 \mathrm{mg}$ ), and is now available for the prevention of TF. It is given as a single intramuscular injection, with a re-vaccination recommended every three years. It is well tolerated and has a proven efficacy, with a protection rate averaging $70 \%$ in hyper-endemic countries.

Almost all polysaccharide vaccines induce a poor immune response in infants below 2 years of age-providing only short-lived antibody responses and no booster response. These factors limit the scope of the $\mathrm{Vi}$ vaccine for routine vaccination in areas where $\mathrm{TF}$ is endemic. In order to improve efficacy, and particularly the duration of protection afforded by the vaccine, it is possible to couple the polysaccharide antigen to a protein carrier, which confers T-cell dependent properties on the conjugate. Such conjugate polysaccharide vaccines elicit the production of specific IgG in infants and have a booster effect after two doses, as has already been shown with Haemophilus influenzae type $\mathrm{b}$ vaccines.

The tolerance and the immunogenicity of a Vi conjugate vaccine (Vi-TT), in which $0.010 \mathrm{mg}$ of purified Vi polysaccharide is bound to a purified, detoxified tetanus toxoid, was studied in a Phase I trial performed in France. In this randomised, double blind, controlled study, the vaccine was administered intramuscularly to 52 healthy male or female volunteers (sex ratio 1/1), aged 19 to 33 years. Subjects received at an interval of one month either two injections of Vi-TT, or one injection of TyphimVi® followed by one injection of placebo. Immediate safety was monitored for 3 hous following each vaccination, and local and systemic events were checked every 2 weeks until Day 56. After the first injection, immediate reactions were experienced by $50 \%$ of subjects in the ViTT group, and in $65 \%$ in the Typhim Vi® group. The reactions were mostly spontaneous pain, not necessarily associated with redness and induration. After the first dose, local reactions were reported by $81 \%$ subjects in the Vi-TT group compared with $65 \%$ of subjects in the Typhim Vi® group. Fewer local reactions were reported after the second dose. Systemic reactions following the first dose reported in the ViTT and Typhim ${ }^{\circledR}$ Vi group, respectively, were body temperature $\geq 38^{\circ} \mathrm{C}$ ( $8 \%$ vs $4 \%$ ), nausea ( $4 \%$ vs $0 \%$ ), and headache ( $4 \%$ vs $8 \%$ ). Corresponding figures following the second dose were body temperature $\geq$ $38^{\circ} \mathrm{C}$ ( $4 \%$ vs $0 \%$ ), asthenia ( $4 \%$ vs $0 \%$ ), and headache ( $4 \%$ vs $0 \%$ ). No serious adverse event was reported in either group.

Blood samples for anti-Vi antibody determination by radio-immunoassay (RIA) were obtained before and 4 weeks after each injection. Prior to vaccination, seroprotection, defined as percentage of subjects with anti-Vi antibody titres $\geq 1 \mu \mathrm{g} / \mathrm{ml}$, was $23.0 \%$ in the Vi-TT group and $11.5 \%$ in the Typhim $\mathrm{Vi}{ }^{\circledR}$ group. Four weeks after the first injection, all subjects vaccinated with the conjugate vaccine were seroprotected, compared with $88.5 \%$ in the Typhim Vi® group. Four weeks after the second dose of vaccine, all subjects in the Vi-TT group were still seroprotected, compared with $92.3 \%$ in the group Typhim $\mathrm{Vi} \circledast$. Seroconversion, defined as fourfold increase in anti-Vi antibody titres from baseline level, was achieved after the first dose by $80.7 \%$ of vaccinees in the Vi-TT group compared with $73.0 \%$ in the Typhim $\mathrm{Vi}{ }^{\circledR}$ group, increasing to $84.6 \%$ and $69.2 \%$, respectively, after the second dose.

A significant difference in favour of the conjugate vaccine was found at D56. (Tukey studentized ranged test, $\mathrm{p}<0.05)$ with an anti-Vi antibody geometric mean titre (GMT) values of $6.8 \mu \mathrm{g} / \mathrm{ml}$ and $3.0 \mu \mathrm{g} / \mathrm{ml}$ for $\mathrm{Vi}$-TT and Typhim Vi®, respectively, As already reported with other polysaccharide-protein conjugate vaccine, the second dose did not elicit a booster response in these young adults. In summary, these data clearly show that the conjugate vaccine was safe and well tolerated, and conferred in health adults a better 
immune response against Salmonella typhi than did Vi polysaccharie vaccine alone.

Since TF and Hepatitis A (HA) are two contagious transmitted via the faecal-oral route with similar epidemological profiles, a combined vaccine, countaining a hepatitis A vaccine (Avaxim $^{\mathrm{TM}}$, Pasteur Mérieux Connaught, Lyon, France; 160 antigen units) and the Typhim Vi polysaccharide vaccine, was tested. In a Phase I study performed in France, 45 adult volunteers received a single $0.5 \mathrm{~mL}$ dose of the combined vaccine by the intramuscular route. The objectives of this study were to compare the safety and immunogenicity of this combination vaccine with data from historical references. Fourteen subjects $(31 \%)$ experienced mild transient local pain after vaccination, and none presented with redness or induration. Systemic reactions reported included headache (20\%), asthenia (18\%), vomiting (4\%), and diarrhoea (4\%). No significant modification of nor- mal clinical laboratory values was observed. Anti-Vi antibody GMT values (RIA)increased from 0.15 $\mathrm{mg} / \mathrm{ml}$ before vaccination to $2.04 \mu \mathrm{g} / \mathrm{ml}$ at 28 days after vaccination. The $\mathrm{Vi}$ seroprotection rate was $86.4 \%$, and the seconversion rate was $90.9 \%$. Among initially HAV-negative subjects, anti-HAV antibody GMT values (modified RIA assay) increase from $5.36 \mathrm{mIU} / \mathrm{ml}$ prior to vaccination to $176.9 \mathrm{mIU} / \mathrm{ml}$, 28 days after injection. At that time, all subjects were considered as seroprotected; $100 \%$ having anti-HAV antibody titres $\geq 20 \mathrm{mIU} / \mathrm{ml}$.

In conclusion, in this preliminary study, the combined $\mathrm{Vi}$ and $\mathrm{HA}$ vaccine was safe and immunogenic, with results similar to those classically obtained with either monovalent vaccine. In the coming years, we can look forward to important advances in the development of these new vaccines against infectious diseases that will be of benefit to both children and adults living in endemic countries. 